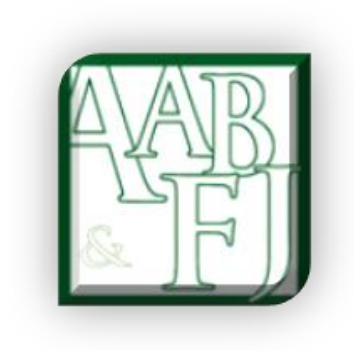

\title{
Editorial Volume 14 Issue 4
}

\author{
Ciorstan Smark $^{1}$
}

This issue of AABFJ takes place during a difficult time for students, academics and universities across the World. While many of us have gained a greater knowledge of distance learning and communication technology, the increasing work-related stress and financial strain have been significant at a time when our social connections to family, colleagues and friends have become more limited.

Articles related to Asia published in this issue include, firstly, Dewi, Febrian, Effendi and Anwar (2020) investigating the level of financial literacy in millennial generation Indonesians. Secondly, Alam, Hassan, Bowyer and Reaz (2020) investigate the garment industry in Bangladesh and find relationships between wages, benefits, welfare facilities and work motivation and employee productivity. Maslow's Hierarchy of Needs Theory is used in this investigation.

In this issue, we also bring together two Australian studies. Firstly, Mazzola, Gerace and Reich (2020) investigate whether ASIC's revisions to RG111 and RG112 have led to an improvement in the information quality of independent expert reports used in Australian takeovers. Secondly, Mollik, Mir, McIver and Bepari (2020) examine earnings management behaviour by Australian firms during the Global Financial Crisis and whether audit quality and the makeup of audit committees influenced this behaviour.

In an unusual article for AABFJ in the geographical sense, Vedernikova, Siguenza-Guzman, Pesantez and Arcentales-Carrion (2020) apply new costing measures, specifically, TimeDriven Activity-Based Costing (TDABC) to the assembly industry in Ecuador and compares the outcomes to traditional costing methods using a case study.

In 2021, AABFJ looks forward to presenting a special issue related to COVID 19 as well as a selection of accounting and finance articles focussing on, but not limited to, Australasia. We hope that our readers and authors are staying safe and dealing with this challenging year as well as is possible.

\footnotetext{
${ }^{1}$ University of Wollongong, Australia
} 


\section{References}

Alam, Mohammad Nurul; Hassan, Md Mahmudul; Bowyer, Dorothea; and Reaz, Md, The Effects of Wages and Welfare Facilities on Employee Productivity: Mediating Role of Employee Work Motivation, Australasian Accounting, Business and Finance Journal, 14(4), 2020, 38-60. doi:10.14453/aabfj.v14i4.4

Dewi, Vera; Febrian, Erie; Effendi, Nury; and Anwar, Mokhamad, Financial Literacy among the Millennial Generation: Relationships between Knowledge, Skills, Attitude, and Behavior, Australasian Accounting, Business and Finance Journal, 14(4), 2020, 2437. doi:10.14453/aabfj.v14i4.3

Mazzola, Paul; Gerace, Dionigi; and Reich, Adam, Quality of Independent Expert Reports Used in Australian Takeovers, Australasian Accounting, Business and Finance Journal, 14(4), 2020, 61-84. doi:10.14453/aabfj.v14i4.5

Mollik, Abu T.; Mir, Monir; McIver, Ron; and Bepari, Md. Khokan, Effects of Audit Quality and Audit Committee Characteristics on Earnings Management During the Global Financial Crisis - Evidence from Australia, Australasian Accounting, Business and Finance Journal, 14(4), 2020, 85-115. doi:10.14453/aabfj.v14i4.6

Vedernikova, Olga; Siguenza-Guzman, Lorena; Pesantez, Johanna; and Arcentales-Carrion, Rodrigo, Time-Driven Activity-Based Costing in the Assembly Industry, Australasian Accounting, Business and Finance Journal, 14(4), 2020, 3-23. doi:10.14453/aabfj.v14i4.2 